DOI

\title{
ДІЯ ЕКСТРАКТУ ЕХІНАЦЕЇ ПУРПУРОВОЇ І ТІОТРІАЗОЛІНУ НА ГЛИБИНУ ЯМОК СЛИЗОВОЇ ОБОЛОНКИ ПІЛОРИЧНОГО ВІДДІЛУ ШЛУНКА ЩУРІВ В УМОВАХ ІНГАЛЯЦІЙНОГО ВВЕДЕННЯ ЕПІХЛОРГІДРИНУ
}

\author{
๑А. С. Смірнов, С. М. Смірнов, М. А. Мірзебасов \\ Державний заклад "Луганський державний медичний університет», Рубіжне
}

РЕЗЮМЕ. В експериментах на білих щурах чоловічої статі було вивчено особливості впливу епіхлоргідрину на слизову оболонку шлунка та на глибину ямок пілоричного відділу шлунка. Було оцінено можливість використання естракту ехінацеї пурпурової та тіотріазоліну для корекцій наявних змін. Було показано, що епіхлоргідрин спричинює збільшення на глибині ямок слизової оболонки пілоричного відділу шлунка і залишається на 15 днів після його введення. Рівень зменшення глибини поступово знижується. Використання екстракту ехінацеї пурпурової на фоні епіхлоргідрину знижує рівень зменшення глибини ямок шлунка, спричинене епіхлоргідрином. Використання тіотріазоліну зменшує тривалість впливу введеного епіхлоргідрину на глибину ямок шлунка.

КлЮчОВІ СлОВА: шлунок, слизова оболонка, епіхлоргідрин, екстракт ехінацеї пурпурової, тіотріазолін.

Вступ. В останні роки спостерігається стійка тенденція до збільшення числа випадків виникнення захворювань органів травної системи. Захворюваність органів травної системи займає одне з перших місць в структурі захворюваності сучасного людства $[1,2,4]$. Порушення стану шлунка найчастіше пов'язані зі змінами, що відбуваються в його слизовій оболонці, яка відрізняється значною пластичністю і здатна тонко реагувати на різноманітні впливи екзогенної і ендогенної природи $[6,7,10]$. Надходження в організм людини епоксидів і з'єднань, до складу яких входить епоксидна група, таких як епіхлоргідрин, викликає розвиток порушень багатьох органів і, в тому числі, шлунка $[3,5,8,9]$. Однак закономірності впливу епіхлоргідрину на слизову оболонку пілоричного відділу шлунка практично не вивчені. У зв'язку з цим експериментальні обґрунтування застосування адаптогенів і антиоксидантів для корекції змін, що виникають, розроблені недостатньо.

Мета дослідження. Вивчити характер впливу епіхлоргідрину на слизову оболонку пілоричного відділу шлунка і на глибину шлункових ямок, а також оцінити можливість застосування екстракту ехінацеї пурпурової і тіотриазоліну для корекції змін, що виникають.

Дослідження проведене в рамках плану наукових досліджень Дз «Луганський державний медичний університет» і $\epsilon$ частиною науководослідної роботи «Структурно-фунуціональний стан тканин в умовах дії екзогенних і ендогенних факторів і корекція змін, що виникають в умовах дії цих факторів» (номер держреєстрації № 0112U002870), а також частиною науково-дослідної роботи «Стан тканин в умовах дії екзогенних та ендогенних факторів і шляхи корекції змін, які викликані цими факторами» (номер держреєстрації № 0116U006014).
Матеріал і методи дослідження. Експеримент проводили з використанням білих безпородних статевозрілих щурів-самців, з яких формували шість експериментальних груп по тридцять тварин у кожній. Щури першої групи були контролем. Щури другої експериментальної групи два місяці п'ять днів на тиждень протягом п'яти годин у день піддавалися інгаляційоному впливу епіхлоргідрину в дозі 10 ГДК (10 мг/кг). Щури третьої експериментальної групи протягом двох місяців по п'ять днів на тиждень через шлунковий зонд отримували екстракт ехінацеї пурпурової по 200 мг/кг маси тіла. Щурам четвертої експериментальної групи протягом двох місяців п'ять днів на тиждень інтраперитонеально в дозі 117,4 мг/кг маси тіла вводили 2,5 \% розчин тіотріазоліну. Щури п'ятої експериментальної групи отримували епіхлоргідрин і екстракт ехінацеї пурпурової, щури шостої експериментальної групи - епіхлоргідрин і тіотріазолін.

Після двомісячного введення епіхлоргідрину, екстракту ехінацеї пурпурової і тіотріазоліну на першу, сьому, п'ятнадцяту, тридцяту і на шістдесяту добу під наркозом із застосуванням хлороформу виводили з експерименту по шість щурів з кожної експериментальної групи. Шлунок фіксували в 10 \% розчині нейтрального формаліну. Гістологічну обробку виконували за стандартною методикою шляхом зневоднення в розчинах етилового спирту з подальшим видаленням спирту за допомогою ксилолу. Препарати заливали в парафін. Для вивчення структури шлунка його зрізи фарбували гематоксиліномеозином і за Ван-Гізон. Мікроскопіювання проводили за допомогою лабораторного мікроскопа серії MC 100 фірми Мicros (Австрія). Із застосуванням програми «Microvisible» визначали глибину шлункових ямок слизової оболонки 
Огляди літератури, оригінальні дослідження, погляд на проблему

пілоричного відділу шлунка щурів. Статистичну обробку отриманих результатів проводили з використанням програми Excel. Для визначення достовірності відмінностей використовували критерій U Манна-Уїтні. Відмінності вважали достовірними при $\mathrm{p}<0,05$.

Результати й обговорення. Під впливом інгаляцій епіхлоргідрину глибина шлункових ямок слизової оболонки пілоричного відділу шлунка виявилася меншою, ніж у інтактних щурів контрольної групи на першу, сьому і п'ятнадцяту добу на $25,8 \%(p<0,01), 21,9 \%(p<0,01)$ i $19,1 \%(p<0,01)$ відповідно. У щурів, які отримували епіхлоргідрин, у міру збільшення терміну, що пройшов після закінчення його введення, відбувалося поступове збільшення глибини шлункових ямок, яке склало за шістдесятидобовий період спостереження 40,2 \% ( $<<0,01)$ (табл. 1).

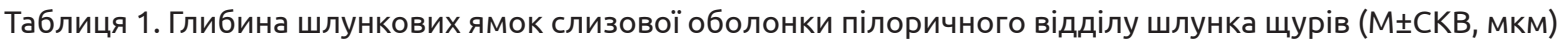

\begin{tabular}{|c|c|c|c|c|c|c|c|}
\hline $\begin{array}{c}\text { Доба } \\
\text { спосте- } \\
\text { режен- } \\
\text { ня }\end{array}$ & $\begin{array}{c}\text { Кіль- } \\
\text { кість } \\
\text { груів в }\end{array}$ & $\begin{array}{c}\text { Контрольна } \\
\text { група }\end{array}$ & $\begin{array}{c}\text { Після інгаля- } \\
\text { цій епіхлор- } \\
\text { гідрину }\end{array}$ & $\begin{array}{c}\text { Після введен- } \\
\text { ня екстракту } \\
\text { ехінацеї } \\
\text { пурпурової }\end{array}$ & $\begin{array}{c}\text { Після } \\
\text { введення } \\
\text { тіотріазоліну }\end{array}$ & $\begin{array}{c}\text { Після введення } \\
\text { епіхлоргідринуу } \\
\text { і екстракту } \\
\text { ехінацеї } \\
\text { пурпурової }\end{array}$ & $\begin{array}{c}\text { Після введення } \\
\text { епіхлоргідри- } \\
\text { ну і тіотріазо- } \\
\text { ліну }\end{array}$ \\
\hline 1 & 6 & $182,45 \pm 10,24$ & $135,32 \pm 10,74^{*}$ & $194,89 \pm 11,39$ & $185,54 \pm 11,50$ & $157,76 \pm 10,83^{* \#}$ & $169,43 \pm 9,59^{\#}$ \\
\hline 7 & 6 & $176,55 \pm 10,28$ & $137,87 \pm 8,86^{*}$ & $191,50 \pm 11,49^{*}$ & $183,98 \pm 13,38$ & $159,30 \pm 16,03^{* \#}$ & $161,41 \pm 9,31^{* \#}$ \\
\hline 15 & 6 & $181,85 \pm 11,73$ & $147,21 \pm 11,87^{*}$ & $180,76 \pm 11,42^{*}$ & $188,34 \pm 12,04$ & $164,09 \pm 10,47^{* \#}$ & $179,17 \pm 11,72^{*}$ \\
\hline 30 & 6 & $182,00 \pm 8,94$ & $180,15 \pm 9,83$ & $183,27 \pm 10,44$ & $187,25 \pm 8,22$ & $182,80 \pm 10,79$ & $178,68 \pm 8,92$ \\
\hline 60 & 6 & $181,66 \pm 10,07$ & $189,72 \pm 9,80^{*}$ & $183,80 \pm 8,28$ & $184,31 \pm 9,25$ & $177,89 \pm 10,00^{\# \star}$ & $178,16 \pm 10,04^{\# x}$ \\
\hline
\end{tabular}

Примітки:

* - p <0,05 в порівнянні з показниками інтактних щурів контрольної групи;

\# - p <0,05 в порівнянні з показниками щурів, яким проводили інгаляції епіхлоргідрину;

$\mathrm{x}-\mathrm{p}<0,05$ при порівнянні показників щурів однієї експериментальної групи в різні терміни спостереження.

В умовах, що склалися після закінчення введення екстракту ехінацеї пурпурової, глибина шлункових ямок слизової оболонки пілоричного відділу шлунка щурів відрізнялася від такої у інтактних щурів контрольної групи, що проявлялося в її збільшенні на сьому добу дослідження на $8,5 \%(p<0,05)$. Глибина шлункових ямок в експериментальній групі щурів, на яких діяв екстракт ехінацеї пурпурової, з плином часу зменшувалася. У період з першої по п'ятнадцяту добу спостереження зменшення склало $7,3 \%(p<0,05)$, але в подальшому зміни даного показника не були статистично значущими ( $p>0,05)$.

Введення тіотріазоліну не викликало змін глибини шлункових ямок слизової оболонки пілоричного відділу шлунка щурів по відношенню до такої у інтактних щурів контрольної групи ( $>>0,05)$. В експериментальній групі щурів, яким вводили тіотріазолін, глибина шлункових ямок протягом шістдесятидобового періоду спостереження змінювалася статистично недостовірно ( $>0,05)$ (табл. 1).

У порівнянні з глибиною шлункових ямок слизової оболонки пілоричного відділу шлунка інтактних щурів контрольної групи даний показник у щурів після введення епіхлоргідрину і екстракту ехінацеї пурпурової був меншим на першу добу на $13,5 \%(p<0,01)$, на сьому добу на $9,8 \%$ $(p<0,05)$, на п'ятнадцяту добу на $9,8 \%(p<0,05)$.
Зіставлення глибини шлункових ямок у щурів, які перенесли інгаляції епіхлоргідрину, і у щурів, яким вводили епіхлоргідрин і екстракт ехінацеї пурпурової, дозволило встановити, що у останніх глибина шлункових ямок виявилася більшою на першу, на сьому і на п'ятнадцяту доби відповідно на $16,6 \%(p<0,01), 15,5 \%(p<0,01)$ i $11,5 \%(p<0,05)$, але меншою на шістдесяту добу на $6,2 \%(p<0,05)$. Часова динаміка змін аналізованого показника в експериментальній групі щурів, які отримували епіхлоргідрин і екстракт ехінацеї пурпурової, характеризувалася тим, що в період з першої по шістдесяту добу глибина шлункових ямок хвилеподібно збільшувалася на $12,8 \%(p<0,05)$.

В експериментальній групі щурів, яким вводили епіхлоргідрин і тіотріазолін, спостерігалося зменшення глибини шлункових ямок слизової оболонки пілоричного відділу шлунка на сьому добу дослідження, порівняно зі значеннями даного показника у інтактних щурів контрольної групи на 8,6 \% $(p<0,05)$. У щурів на першу, сьому $\mathrm{i}$ на п'ятнадцяту доби після закінчення проведення інгаляцій епіхлоргідрину і ін'єкцій тіотріазоліну глибина шлункових ямок була більшою, ніж у щурів, яким вводили епіхлоргідрин, відповідно на $25,2 \%(p<0,01), 17,1 \%(p<0,01)$ i $21,7 \%(p<0,01)$, а на шістдесяту добу спостерігалося зменшення глибини ямок на $6,1 \%(p<0,05)$. У часовій динаміці змін глибини шлункових ямок щурів, які 
Огляди літератури, оригінальні дослідження, погляд на проблему

отримували епіхлоргідрин і тіотріазолін, в період з першої по сьому добу не було відзначено статистично значущих змін ( $p>0,05)$, однак протягом часового проміжку між сьомою і шістдесятою добами відбувалося збільшення даного показника на $10,4 \%(p<0,05)$.

Висновки. Результати роботи свідчать про те, що епіхлоргідрин здатний викликати зміни в слизовій оболонці шлунка, що узгоджується з результатами інших досліджень [3], і дозволяють зробити наступні висновки щодо характеру його впливу на слизову оболонку пілоричного відділу органа, а також про можливості застосування екстракту ехінацеї пурпурової і тіотріазоліну для корекції змін, що виникають.

1. Епіхлоргідрин викликає зменшення глибини шлункових ямок слизової оболонки пілоричного відділу шлунка, яке зберігається протягом п'ятнадцяти діб після припинення його введення.

\section{ЛІТЕРАТУРА}

1. Беляева Ю. Н. Мониторинг распространенности болезней органов пищеварения и смертности от них в Саратовской области с использованием ГИСтехнологий / Ю. Н. Беляева, Г. Н. Шеметова, Д. П. Хворостухин // Практикуючий лікар. - 2013. - № 3 (7). C. $59-62$.

2. Бойко Т. Й. Епідеміологія та чинники ризику хронічних неспецифічних запальних захворювань кишечника / Т. Й. Бойко // Сучасна гастроентерологія. - 2013. № 4 (72). - С. 129-133.

3. Структурні зміни слизової оболонки і підслизового прошарку шлунка щурів, що виникають під впливом епіхлоргідрину / С. М. Смірнов, М. Л. Кувеньова, А. С. Смірнов, О. М. Россомахіна // Український морфологічний альманах. - 2013. - Т. 11, № 4. - С. 74-76.

4. Соломенцева Т. А. Хронический гастрит с позиции канцерпревенции. Эволюция представлений / Т. А. Соломенцева // Сучасна гастроентерологія.-2013.№ 4 (72), С. 135-140.

5. Загрязнение воздушной среды хлорорганическими углеводородами в производствах поливинилхлорида и эпихлоргидрина / Н. А. Тараненко, Н. М. Ме-
2. У щурів, яким не проводили інгаляції епіхлоргідрину, введення екстракту ехінацеї пурпурової супроводжується незначним і короткочасним збільшенням глибини шлункових ямок слизової оболонки пілоричного відділу шлунка, а введення тіотріазоліну не викликає змін їх глибини.

3. Застосування екстракту ехінацеї пурпурової на тлі введення епіхлоргідрину знижує ступінь зменшення глибини шлункових ямок, викликаного епіхлоргідрином.

4. Використання тіотріазоліну зменшує виразність і скорочує тривалість індукованого епіхлоргідрином зменшення глибини шлункових ямок.

Перспективи подальших досліджень. Подальші дослідження закономірностей дії ксенобіотиків, в тому числі епіхлоргідрину, дозволять отримати цінну наукову інформацію про механізми розвитку змін у слизовій оболонці шлунка, що дасть можливість розробити ефективні методи профілактики та корекції змін, що виникають.

щакова, О. М. Журба, В. В. Тележкин // Гигиена и санитария. - 2014. - № 4. - С. 47-51.

6. From gastroprotective to ulcerogenic effects of glucocorticoids: role of long-term glucocorticoid action / L. Filaretova, T. Podvigina, T. Bagaeva, O. Morozova // Curr. Pharm Des. - 2014. - № 20(7). - P. 1045-1050.

7. Esophagoprotection mediated by exogenous and endogenous melatonin in an experimental model of reflux esophagitis / P. C. Konturek, I. Brzozowska, A. Targosz [et al.] // J. Pineal Res. - 2013. - P. 46-57.

8. Apoptotic cell death in rat epididymis following epichlorohydrin treatment / I.C. Lee, K.H. Kim, S.H. Kim [et al.] // Hum. Exp. Toxicol. - 2013. - № 32 (6). - P. 640-646.

9. One-generation reproductive toxicity study of epichlorohydrin in Sprague-Dawley rats / I. S. Shin, N. H. Park, J. C. Lee [et al.] // Drug Chem Toxicol. - 2010. - № 33 (3). P. 291-301.

10. Taurine zinc solid dispersions protect against coldrestraint stress-induced gastric ulceration by upregulating HSP70 and exerting an anxiolytic effect / C. Yu, X. T. Mei, Y. P. Zheng, D. H. Xu // Eur. J. Pharmacol. - 2015. - № 762. P. 63-71.

\section{THE ACTION OF THE EXTRACT OF ECHINACEA PURPUREA AND THIOTRIAZOLINE ON DEPTH OF PITS OF PYLORIC MUCOUS MEMBRANE OF THE STOMACH OF RATS UNDER INHALATION EPICHLOROHYDRIN}

\section{@A. S. Smirnov, S. M. Smirnov, M. A. Mirzebasov \\ Luhansk State Medical University, Rubizhne}

SUMMARY. In experiments on white male rats there were studied the regularities of the influence of epichlorohydrin on the mucous membrane of the stomach and on the depth of pits of pyloric stomach. We evaluated the possibility of using an extract of Echinacea purpurea and thiotriazoline for correction occurring changes. It was shown that epichlorohydrin causes a decrease in the depth of the pits of gastric mucosa pyloric part of the stomach that persists for fifteen days after the cessation of its administration. The degree of reduction of the depth gradually decreases. The use of the extract of Echinacea purpurea on the background of epichlorohydrin lowers the degree of reducing the depth of gastric pits caused by epichlorohydrin. Using thiotriazoline reduces the severity and shortens duration epichlorohydrin induced decrease the depth of the gastric pits.

KEY WORDS: stomach, mucous membrane, epichlorohydrin, the extract of Echinacea purpurea, thiotriazoline. 